Volume 3, Issue $1 \cdot 2011 \cdot$ Article 7

\title{
The Perversion of Scientific Evidence for Policy Advocacy: A Perspective on Avery 2010
}

Richard Fielding, The University of Hong Kong

Fielding, Richard (2011) "The Perversion of Scientific Evidence for Policy Advocacy: A Perspective on Avery 2010," World Medical \& Health Policy: Vol. 3: Iss. 1, Article 7.

Available at: http://www.psocommons.org/wmhp/vol3/iss1/art7

DOI: $10.2202 / 1948-4682.1155$ 


\title{
The Perversion of Scientific Evidence for Policy Advocacy: A Perspective on Avery 2010
}

\author{
Richard Fielding, The University of Hong Kong
}

\begin{abstract}
The claims of scientific misconduct surrounding the pandemic influenza event in 2009 and the furor surrounding purported scientific manipulation at the University of East Anglia's Climate Research Unit were used as grounds in Avery's 2010 paper to ostensibly criticize how science is corrupted by the need to support particular political or ethical perspectives and, implicitly, that such perspectives are either lacking in evidence, or that such evidence is distorted or suppressed to maintain the politically correct interpretation. However, this rejoinder to Avery's paper demonstrates unambiguously that both unbalanced interpretation and one-sided presentation of opinion as evidence in support of these claims is in fact a thinly disguised attack on two issues that are contentious to certain vested interests. Having written the original paper on which Avery 2010 is based for a think tank well known for its opposition on ideological grounds to both environmental legislation and anthropogenic global warming, and for which some funding was received, Avery undermines his own arguments by appearing to embody the very problem he seeks to reveal. This rejoinder details why that seems to be the case.
\end{abstract}

KEYWORDS: scientific evidence, global warming, corporate funding, think tanks

Author Notes: Conflict of interests: None declared. No funding was received in respect of this submission. The author confirms that there was no material or pecuniary interest in any business or organization associated with, or benefit in any material way from, the publication of this work. The author is not a member of any organization that has such interests. The opinions expressed are his own and not those of his employing organization. Corresponding author: Richard Fielding PhD, FFPH, FHKPsS, AFBPS, Professor of Medical Psychology in Public Health, Department of Community Medicine \& Unit for Behavioural Sciences, and Deputy Head (Advocacy), School of Public Health, 5/f, WMW Mong Block, Li Ka Shing Faculty of Medicine Building, The University of Hong Kong, 21, Sassoon Road, Pokfulam, Hong Kong SAR, China. Email: fielding@hku.hk 
Fielding: A Perspective on Avery 2010

"Democracy depends not on the preferences of elites, but rather on a functional marketplace for ideas and vigorous debate between contending viewpoints." (Avery 2010)

George H. Avery's recent invited paper "Scientific Misconduct: The Perversion of Scientific Evidence for Policy Advocacy" (Avery 2010) potentially presents a beautiful illustration of the very phenomenon that he seeks to critique, when arguing that science is being distorted for political ends to justify particular policy objectives.

The argument stated early in the paper that "Increasingly, however, science is being manipulated by those who try to use it to justify political choices based on their ethical preferences, and who are willing to act to suppress evidence of conflict between those preferences and the underlying reality." cites a Los Angeles Times report which found that half of the staff interviewed from the Food \& Drug Administration (FDA) and the U.S. Department of Agriculture (USDA) reported interference with work by "corporate or congressional sources." Nowhere is this truer than regarding the energy, extraction, and agricultural policies of the United States, where these commercial interests comprise some of the largest corporate donors to congressional elected officials, and who expect in return for their support actions that favor those very same commercial interests. Such donors also attempt to exert their influence by a series of other means, including direct involvement in policy setting bodies (Nestle 2007), and through the sponsorship of think tanks, such as the Cato Institute, co-founded by Charles Koch of Koch Industries, the largest oil infrastructure business in the United States. Koch Industries, the second largest private business in the United States, has a long history of exerting influence on policy decision making, by way of substantial campaign contributions (Federal Election Commission), and other means, including sponsorship of the (defeated) Proposition 23 to overturn California's proposed environmental legislation (Goldberg 2010) and financing groups outspoken in their denial of anthropogenic global warming to the tune of US\$73 million (http://www.greenpeace.org/usa/campaigns/global-warming-andenergy/polluterwatch/koch-industries/). The oil industry opposes the idea of climate change because the concept potentially threatens its revenue stream. Avery cites Doremus (2007), who notes that: "scientists can move from 'skeptical evaluation' into advocacy due to 'employment by an entity with a financial stake' in a particular outcome and "other sorts of strong policy preferences"'. On this point Doremus is quite correct, and it is noted in the admirable example of transparent disclosure by Avery that his paper is based on a previous manuscript written and paid for by the Cato Institute. The Cato Institute makes no secret of its strongly free-market, pro-business stance and desire for lax environmental 
standards. Alas, this raises significant concerns that go to the very core of Avery's arguments.

What then are we to make of Avery's arguments, particularly those that repeat the now thrice disproven claims about the University of East Anglia's Climate Research Unit, namely that "leaked" or hacked emails "reveal a pattern of data suppression, manipulation of results, and efforts to intimidate journal editors to suppress contradictory studies and indicate that scientific misconduct has been used intentionally to manipulate a social consensus to support the researchers' advocacy of addressing a problem that may or may not exist." A problem that may or may not exist indeed. Three independent tribunals investigated the UEA CRU "scandal" to which Avery refers, and each concluded that there was no evidence of data falsification, suppression, or manipulation over and above that which is seen in any branch of science involving data collection, which is normally referred to as "data cleaning," "elimination of outliers," and "recoding." No evidence of scientific misconduct was found despite almost 12 months of investigations (Science \& Technology Select Committee 2010; MuirRussell 2010; Randerson 2010). Given the timing of the email release upon which all of the accusations were made, being shortly before the Copenhagen Climate Conference, this scandal was in all likelihood a deliberate attempt to muddy the waters by raising doubt about the nature of the science by vested interests. This strategy was one of the tactics the tobacco industry used to great effect to obfuscate the implementation of tobacco control policies worldwide for decades, and is widely used by a range of industries today to avoid occupational and environmental health restrictions designed to protect public health (Michaels 2008). That Avery overlooks this is surprising.

In describing the buildup to $\mathrm{A} / \mathrm{H} 1 \mathrm{~N} 1$ pandemic influenza, Avery cites several sources in support of his argument, but nowhere do we see mention of how the media contributed to the conflating of "Spanish flu" with "Swine flu," or the explosive spread of scare stories about swine flu across the world's wire services. Most of the hyperbole that Avery remarks on emerged not from scientists of public health groups, but from independent media organizations, such as News International publications. In fact the only papers cited in support of Avery's surprising claim that the public health community was desperately seeking something by which to save its neck is one publication by a graduate student in a religious newspaper, not an academic journal, and a second paper coauthored by Avery himself. Avery does however cite a robust source at the Centers for Disease Control (CDC) that stated the pandemic to be milder than anticipated. There is no doubt that there was a high level of anticipation of a major pandemic at the time A/H1N1 emerged, and with the wisdom of 20:20 hindsight it is easy to criticize changes and choices that were made. However, had this not happened, and there had been instead an epidemic with a 5\% mortality 
rate hundreds of thousands of avoidable deaths worldwide would have occurred. What then would have been the reaction? The precautionary principle has its purposes. There is also no doubt that the credibility of the public health community has declined, and this is in no small part due to the rapid willingness of media commentators to show no mercy when predictions are inaccurate, or associated with error margins that prevent clear claims being made. There is evidence that risks from vaccination were seen by the general public to be greater than those from $\mathrm{A} / \mathrm{H} 1 \mathrm{~N} 1$ influenza, leading to high levels of rejection of vaccination. There is no doubt that the funding of scientists by commercial organizations that stand to gain from health scares generates conflicts of interest, with increasing numbers of scientists seeking commercial funding as public funding is withdrawn. There is also little doubt that as these conflicts come to light, they further erode the credibility of science in the eyes of the public. An increasing number of scientists are becoming shills for particular industries, as many were for the tobacco industry. A growing number of scientists in private "consultancies" effectively sell whatever results are required by the people who buy their services (Michaels 2008): He who pays the piper calls the tune. In this regard, some scientists have become like the large accounting companies who approve the books of corporations such as Enron. This is compounded as stories emerge of scientists whose results are found to be fraudulent for career or financial gain.

But it is the second section of Avery's paper that suggests that Avery is a pot calling the kettle black. First, the explicit accusations of fraud and manipulation leveled at the UEACRU scientists completely omit the fact that none of the accusations have stood up to scrutiny (Science \& Technology Select Committee 2010; Muir-Russell 2010; Randerson 2010). Second, Avery states: "The reasons behind this misconduct are clear. The tactics of those who wish to impose political change to address environmental issues consist largely of convincing the population and political leaders that the existence and threat of manmade global warming is a settled issue, based on a consensus of scientific information (Michaels 2008; Taranto 2009)". It is noteworthy that the two papers by Michaels and Taranto that Avery cited in support of this statement are published by the Cato Institute and the Wall Street Journal respectively, neither known for balanced reporting on climate issues. Where is the peer-reviewed science that shows the uncertainty in the near consensus on anthropogenic global warming? Please present it so we can see the evidence that challenges the mainstream consensus. But no, such evidence is never presented in pieces such as Avery's or indeed the source papers. Instead, innuendo suffices. In other words, Avery is repeating opinion, not fact here. From this criticism of the UEACRU email "scandal," Avery's arguments spread to a network of other related "scandals" all referenced against researchers who have either themselves received 
funding from industry sources, or whose theoretical work has been disproven by mainstream science, but who have been unwilling to accede that perhaps their theories are simply incorrect. Nonetheless, apparent "scandal" after "scandal" is wheeled out in support of this conspiratorial corruption. The problem is that this is all opinion, not fact, and Avery fails to sustain his arguments with evidence. Nor is the piece balanced. For example, there is no mention of how White House staffers under the last Bush administration selectively deleted parts of scientific reports on global warming that they did not like or felt awkward about, or how political appointments of industry personnel in federal agencies attempted to influence the work that those agencies performed in a way that favored their former industries. There is no discussion of the fact that tired old arguments against anthropogenic climate change, so-called zombie arguments (because despite being killed they don't lie down), have all been disproven, but nonetheless climate change skeptics continue to raise these ignoring both calls for evidence and clear failings in the arguments. It is a well-known political strategy that when you cannot defeat the message, then the next best thing is to shoot, or at least discredit, the messenger. This appears to be the intent of Avery's paper. From its own origins as an opinion piece for an organization that is outspoken in its opposition to environmental laws and anthropogenic global warming on ideological, not evidential grounds, through to the admission of funding in return for this piece, Avery embodies the very problem he seeks to raise: that of doubt about the veracity and objectivity of the evidence for arguments made in his paper. This, as 2010 is pronounced the joint warmest year on record (NOAA 2011), is, at the very least, irresponsible.

The deliberate spread of misinformation about climate science is intentional and targeted, and includes funding for groups and public relations companies tasked with maintaining high-profile objections and challenges at each and every opportunity (Michaels 2008) and fake grass-roots objections (astroturfing) (Beder 2002) supported by direct funding from the hydrocarbon industries, among others (Vidal 2010). These activities are well documented. It is disappointing to see what could have been an important contribution to the clear problems of entanglement between science and industry in the public policy arena fail to reach the standard the very article seems to expect of others.

Avery states in his conclusion: "Equally important from the perspective of science is that it undermines the credibility that is derived from the scientific traditions that promote dispassionate objectivity." It is hard to see the dispassionate objectivity in the paper that Avery seeks here. He ends with this: "Private organizations lack the coercive power of government, and no private organization-even large and wealthy corporations in the energy or pharmaceutical industries-possesses the power and resources of governments." Avery fails to consider that organizations largely dictate to governments how they 
should behave, both through financial support at election time through to the staffing of key government positions with people beholden to specific industries, such as Wall Street investment banks and the extraction and arms industries (Hartung and Ciarrocca 2004). In effect, government is largely subservient to these large organizations. Finally, Avery would be wise not to under-estimate how effectively such organizations have in the past succeeded in manipulating (the tobacco, asbestos, vinyl industries, for example; Michaels 2008), and in the present (the hydrocarbon industries) continue to manipulate public opinion by way of public relations and grass-roots organizations, misinformation, and think tanks.

\section{References}

Avery, G.H. 2010. "Scientific Misconduct: The Perversion of Scientific Evidence for Policy Advocacy." World Medical and Health Policy 2 (4): 17-31.

Beder, S. 2002. Global Spin: The Corporate Assault on Environmentalism. Devon, UK: Green Books.

Doremus, H. 2007. "Scientific and Political Integrity in Environmental PolicyMaking." Texas Law Review 86: 1601-1653.

Federal Election Commission. http://www.fec.gov/finance/disclosure/norindsea. shtml (accessed January 11, 2010).

Goldberg, S. 2010. "Arnold Schwarzenegger Flexes Muscles to Defend ClimateChange Law." The Guardian, $28^{\text {th }}$ September, 2010. http://www.guardian. co.uk/world/2010/oct/28/arnold-schwarzenegger-proposition23-oilclimate-change? INTCMP=SRCH.

Hartung, W.D., and M. Ciarrocca. 2004. "The Ties that Bind: Arms Industry Influence in the Bush Administration and Beyond." World Policy Institute. http://www.worldpolicy.org/projects/arms/reports/TiesThatBind.html.

Michaels, D. 2008. Doubt is Their Product. How Industry's Assault on Science Threatens Your Health. New York: Oxford University Press.

Muir-Russell, A. 2010. "The Independent Climate Change Emails Review." www.cce-review.org/pdf/FINAL\%20REPORT.pdf.

National Oceanic and Atmospheric Administration. 2011. "NOAA: 2010 Tied for Warmest Year on Record." January 12, 2011. http://www.noaanews. noaa.gov/stories2011/20110112_globalstats.html.

Nestle, M. 2007. Food Politics: How the Food Industry Influences Nutrition and Health. Berkeley: University of California Press. 
Randerson, J. 2010. “Climate Researchers 'Secrecy' Criticised - but MPs Say Science Remains Intact". The Guardian, March, 31 3t, 2010. http://www.guardian.co.uk/environment/2010/mar/31/climate-mailsinquiry-jones-cleared?INTCMP=SRCH.

Science \& Technology Select Committee. 2010. "The Disclosure of Climate Data from the Climatic Research Unit at the University of East Anglia." Houses of Parliament. http://www.parliament.uk/business/committees/committees -archive/science-technology/s-t-cru-inquiry/.

Vidal, J. 2010. "US Oil Company Donated Millions to Climate Sceptic Groups, Says Greenpeace." The Guardian, 30 ${ }^{\text {th }}$ March. http://www.guardian.co.uk/ environment/2010/mar/30/us-oil-donated-millions-climatesceptics? $\mathrm{INTCMP}=\mathrm{SRCH}$. 